\title{
Journals in surgery and gastroenterology: indexing in databases and bibliometric indicators ${ }^{1}$
}

\author{
Revistas de cirurgia e gastroenterologia: \\ indexação em bases de dados e indicadores bibliométricos
}

\author{
Regina C. Figueiredo Castro ${ }^{2}$ \\ 1. Full text of presentation held at the Post Graduation Program on Surgical Gastroenterology, Universidade Federal de São Paulo \\ (UNIFESP/EPM), Brazil, in March 2006. \\ 2. Master in Information Science, PhD in Public Health. Coordinator, Health Scientific Communication. BIREME/PAHO/WHO, \\ São Paulo, Brazil
}

\begin{abstract}
Introduction: Publishing research results as journal articles is the most common format used by researchers for dissemination of advancements in science. To select where to publish, authors must know how to identify the most recognized journals in each field, adopting quality criteria.

Purpose: To discuss journal selection criteria and bibliometric indicators for evaluation of scientific production and to analyze the status of indexing of Brazilian and international journals in health science databases, mainly for journals in surgery and gastroenterology fields. Results: The totals of journals indexed in health science databases are presented, highlighting the relative participation of journals in surgery and gastroenterology in each database. Conclusion: The decision to publish in a national or international journal should be based on bibliometric indicators and status of indexing in databases, but the objectives of the research must be the main point considered by authors.
\end{abstract}

Key words: Periodicals. Databases, bibliographic. Bibliometrics. Surgery. Gastroenterology.

\section{RESUMO}

Introdução: A publicação dos resultados de pesquisas em artigos científicos é a forma mais adotada pelos pesquisadores para registro e divulgação dos avanços da ciência. Para decidir onde publicar seus trabalhos, os autores devem saber identificar as revistas científicas mais reconhecidas em cada área, utilizando critérios de qualidade científica. Objetivo: Discutir os critérios de seleção de revistas para publicação e os indicadores bibliométricos utilizados para avaliação da produção científica e analisar o panorama atual de indexação das revistas científicas brasileiras e estrangeiras, em bases de dados da área da saúde, com especial ênfase nas revistas das áreas de cirurgia e gastroenterologia. Resultados: São apresentados os totais de revistas indexadas em bases de dados da área da saúde, destacando os percentuais de revistas das áreas de cirurgia e gastroenterologia em cada base de dados. Conclusão: A decisão de publicar em uma revista estrangeira ou nacional pode ser apoiada pelos indicadores bibliométricos e pela representatividade das revistas em bases de dados, mas deve ser orientada principalmente em função dos objetivos da pesquisa.

Descritores: Publicações periódicas. Bases de dados bibliográficas. Bibliometria. Cirurgia. Gastroenterologia.

\section{Introduction}

Writing scientific papers may be considered the first stage of the scientific communication flow, including: the conception and delimitation of the research object, the retrieval and analysis of existing documents, the research itself and the preparation of papers describing research results for registering knowledge advancements. The delimitation of research objects, the application of scientific methodology and definition of research phases and the follow-up of the results are included in the academic curriculum, especially in post graduation courses. In the academic curricula of health schools there are disciplines specifically devoted to scientific methodology, information retrieval in databases and scientific writing, besides the formal orientation of professors and advisors. Manuals and guidelines for the preparation of academic works, mainly dissertations and theses, are available in universities. However, little information is found about criteria for selecting journals where to publish, according to the research objectives and subject fields. It should be emphasized that the selection of the scientific journal where the article will be published should be made before initiating the drafting and not at the end, as it is usual among researchers. Once the research subject is defined, the researcher should identify the journals that better represent the area of interest and try to publish the paper in one of them. If the main objective of scientific publishing is the dissemination of scientific advances to other researchers of the same area of interest, nothing is better than knowing where the peers are publishing their papers. 
The instructions for authors, which give information on the content coverage and orientation about presentation of articles in scientific journals, constitute the better source for selection of journals for publication. Reading these instructions is necessary before beginning to write the paper, since each journal can adopt specific rules, although there are international standards for presentation of scientific articles and bibliographic references. If authors select the journal where to send the paper after finishing it, they will probably have to modify the text, which is not always as simple as using commands of text processors.

The selection of journals became particularly important for authors, since the systems for academic evaluation of higher education and of the governmental research support agencies are giving special importance to publications in journals with better performance in the international scientific community. And the measures of this performance, which are given by bibliometric or scientometric indicators, often are unknown of the academic community in the health field.

The objective of this article is to discuss some selection criteria of journals for publication and the bibliometric indicators used for appraisal of scientific output. The current panorama of indexing of the Brazilian and foreign scientific journals, in databases of interest to the health field, will be analyzed, with special emphasis on journals of surgery and gastroenterology areas.

\section{Journal indexing in databases}

There are more than 1 million periodicals in the database of ISSN (International Standard Serial Number), which registers each journal published in the world and gives them a unique identifier. Of this total, nearly 40,000 are scientific peer-reviewed journals, i.e. journals which publish scientific articles that are evaluated by members of the academic community.

Scientific journals can be located in different databases:

- Journal catalogs, which record information about the journals, such as ISSN and Latindex databases;

- Bibliographic databases, which index the contents of articles of selected journals, such as MEDLINE and LILACS;

- Citation databases, which indicate the number of citations that journal articles receive from other journals in the universe of indexed titles, such as Science Citation Index and SciELO.

For journals published in Latin America, Caribbean, Spain, and Portugal there is the Latindex system (http://www.latindex.org), coordinated by Universidad Nacional Autónoma of Mexico (UNE), in Mexico. This system is composed by two databases: the first, entitled Directory, registers all the journals published in these countries, which were identified by the collaborators; the second, entitled Catalog, registers scientific peer-reviewed journals, selected by quality criteria. In Directory database, in March 2006, there were 14,640 titles and in Catalog, 2,064 titles. Unfortunately, as input is decentralized, not all the journals published in these countries are included in Latindex. Brazil is sub-represented in this system with 3,322 titles in the Directory and only 247 titles in the Catalog.

The main databases which index health journals are:

- $\quad$ MEDLINE and PubMed, produced by National Library of Medicine (NLM), United States;

- $\quad$ EMBASE, produced by Elsevier, Netherlands;

- $\quad$ LILACS - Latin American and Caribbean Health Sciences Literature, coordinated by the BIREME - Latin American and Caribbean Center on Health Sciences Information, in Brazil, with the contribution of Latin America and the Caribbean countries;

- $\quad$ Science Citation Index (SCI), Science Citation Index Expanded (SCIE) and Social Sciences Citation Index of Thomson Scientific (formerly, Institute for Scientific Information - ISI), United States;

- $\quad$ SciELO - Scientific Electronic Library Online, also coordinated by BIREME, with collections in several countries of Latin America, Spain and Portugal.

Almost all bibliographic and citation databases adopt criteria for editorial quality and content analysis for selection of journals for indexing. The more rigid and transparent the levels of requirement assigned for the selection criteria, the more respected are the databases in the scientific community. Database selection criteria are basically the same, only varying the degree of requirements adopted by each database: scientific quality (including the process of peer review), editorial board, collaboration between authors, type of content, regularity of publication, frequency of publication and standardization. The language is not a restrictive element in databases, although they require at least titles and abstracts in English. Along with these criteria, the Thomson Citation Indexes consider the number of citations received by the journal being evaluated, within the universe of indexed journals in these databases.

With regard to the selection criteria, it is important to point out the difference between MEDLINE and PubMed. The MEDLINE ${ }^{1}$ database is a subset of PubMed, constituted by journals selected in accordance with rigid selection criteria applied by the Literature Selection Technical Review Committee (LSTRC), formed by experts in the health sciences, which meet 3 times a year. PubMed ${ }^{2}$ content is broader and, in addition to MEDLINE citations, includes: citations from OLDMEDLINE file (from 1950 to 1965), citations to out-of-scope articles from certain MEDLINE journals (primarily general science and general chemistry journals), articles of journals that may not have been recommended for inclusion in MEDLINE, in-process citations etc. According to the List of Journals for Online Users 2005 PubMed includes 10,582 titles, 4,026 belonging to OLDMEDLINE and 4,978 to MEDLINE. There are also differences among the selection criteria of journals in MEDLINE: 4,339 titles were selected by the LSTRC for Index Medicus and the other 639 titles correspond to non-Index Medicus journals, in areas such as Dentistry, Nursing, 
Health Care Administration etc., which were selected by other institutions ${ }^{3}$. Users can limit their retrieval to MEDLINE citations in PubMed by selecting MEDLINE in the Subset Menu, if they want to retrieve only journals evaluated by quality criteria.

All databases update periodically the lists of indexed journals:

- $\quad$ NLM publishes every year the List of Journals for Online Users that includes all the titles available in PubMed, and the List of Indexed Journals for $M E D L I N E$, that is organized in alphabetical order, by subject and by country of publication. Journals indexed in MEDLINE also can be searched online in Locator Plus database (http://locatorplus.gov/);

- $\quad$ EMBASE updates the list of indexed journals annually, only in printed format, available by subscription;

- All the journals indexed in Thomson Scientific databases can be searched in the Master Journal List (http://scientific.thomson.com/mjl/), which includes journals indexed in several specialized databases such as Current Contents, Biological Abstracts, Neurosciences Citation Index, Zoological Abstracts etc.; each database has also a specific journal list. The lists of journals indexed in the Citation Indexes are also available since 2005 in PDF format;

- $\quad$ Lists of journals indexed in LILACS can be found in the Virtual Health Library, coordinated by BIREME, in the LILACS Methodology menu, in alphabetical order or by country of publication (http://www.bireme.br/ abd/P/diretorio.htm);

- Alphabetic and subject lists of SciELO journals appear in the module for serials browsing in SciELO site (http://www.scielo.org).

The indexing status of Iberoa-American health scientific journals can also be found in the Virtual Health Library, in Health Scientific Communication area, (http://ccs.bvsalud.org/docs/level2.php? channel=serialt\&graphic=yes\&l).

In December 2005, according to the journal lists, the indexing status of scientific journals in these databases was: 4,978 titles indexed in MEDLINE, 4,874 in EMBASE, 697 in LILACS, 3,772 in Science Citation Index, 6,474 in Science Citation Index Expanded, and 351 in SciELO (151 in SciELO Brazil and 200 in the other national collections). SciELO and the Science Citation Indexes index journals from all knowledge areas.

\section{Indexing status of journals of surgery and gastroenterology subject fields}

Articles on surgery can be published in journals of surgery or scattered in journals of other subject areas or in general health sciences journals. Población et al ${ }^{4,5}$ identified 23 peer-reviewed Brazilian journals that publish articles about surgical techniques and procedures, which were defined as the core journals for the studies conducted by the Research Group on Scientific Communication in Surgery.

Following this trend, the articles on surgical gastroenterology or gastroenterological surgery can be published both in specialized journals of surgery and gastroenterology fields. Therefore, the indexing status of journals will be presented for both subject areas. Table 1 shows the percentages of Brazilian journals and of surgery and gastroenterology journals indexed in the databases.

It is observed that Brazilian journals are little represented in the international databases, in relation to the total of indexed journals. In LILACS and SciELO databases, which index journals published in Latin America and the Caribbean countries, Brazilian journals correspond to $41 \%$ and $54 \%$, respectively.

Concerning the relative percentage of journals in databases, it is greater in surgery than in gastroenterology field, in all databases. The area of surgery is better represented in EMBASE (6.4\%) and less in the citation indexes: $2.3 \%$ in Science Citation Index and 1.1\% in SciELO. Gastroenterology journals correspond to less than 2\% of the total, in all databases, and are little represented also in the citation indexes.

There are 4 Latin American surgery journals indexed in these databases:

- Acta cirúrgica brasileira (Brasil) - em MEDLINE, SciELO e LILACS

- Cirugia y cirujanos (México) - em MEDLINE, SciELO e LILACS

- $\quad$ Revista do Colégio Brasileiro de Cirurgiões (Brasil) em SciELO e LILACS

- $\quad$ Revista cubana de cirugia (Cuba) - em SciELO e LILACS

As well as 5 in the gastroenterology field:

- $\quad$ Acta Gastroenterologica Latinoamericana (Argentina) - em MEDLINE e LILACS

- Arquivos de Gastroenterologia (Brasil) - em MEDLINE, SciELO e LILACS

- GED - Gastroenterologia Endoscopia Digestiva (Brasil) - em MEDLINE e LILACS

- Revista de Gastroenterología de México (México) em MEDLINE e LILACS

- Revista de Gastroenterología del Perú (Peru) - em MEDLINE, SciELO e LILACS 
Table 1 - Presence of journals in surgery and gastroenterology in databases

\begin{tabular}{|l|c|c|c|c|c|c|c|}
\hline Databases & $\begin{array}{c}\text { Total of } \\
\text { Brazilian } \\
\text { Journals }\end{array}$ & $\begin{array}{c}\text { Total of } \\
\text { journals }\end{array}$ & $\begin{array}{c}\text { \% } \\
\text { Brasil* }\end{array}$ & $\begin{array}{c}\text { Total } \\
\text { Surgery }\end{array}$ & $\begin{array}{c}\text { \% } \\
\text { Surgery* }\end{array}$ & $\begin{array}{c}\text { Total } \\
\text { Gastro } \\
\text { enterology }\end{array}$ & $\begin{array}{c}\% \\
\text { Gastro } \\
\text { enterology* }\end{array}$ \\
\hline MEDLINE & 30 & $\mathbf{4 . 9 7 8}$ & $0,6 \%$ & 212 & $\mathbf{4 , 2 \%}$ & 84 & $\mathbf{1 , 7 \%}$ \\
\hline EMBASE & 44 & $\mathbf{4 . 8 7 4}$ & $0,9 \%$ & 313 & $\mathbf{6 , 4 \%}$ & 90 & $\mathbf{1 , 8 \%}$ \\
\hline $\begin{array}{l}\text { JCR 2004 } \\
\text { Science }\end{array}$ & 16 & $\mathbf{5 . 9 6 8}$ & $0,3 \%$ & 139 & $\mathbf{2 , 3 \%}$ & 46 & $\mathbf{0 , 7 \%}$ \\
\hline SciELO & 151 & $\mathbf{3 5 0}$ & $53,6 \%$ & 4 & $\mathbf{1 , 1} \%$ & 3 & $\mathbf{0 , 8} \%$ \\
\hline LILACS & 285 & $\mathbf{6 9 7}$ & $41 \%$ & 29 & $\mathbf{4 , 2} \%$ & 11 & $\mathbf{1 , 6 \%}$ \\
\hline
\end{tabular}

* \% in relation to the total of indexed journals

Source: Lists of journals indexed in each database

\section{Bibliometric indicators}

The bibliometric indicators most used for the appraisal of the scientific output were created by the Institute for Scientific Information (ISI), today Thomson Scientific. These indicators are extracted from Thomson citation databases, known in the Brazilian scientific community simply as ISI databases. These databases are divided in three areas: exact and health sciences (Science Citation Index and Science Citation Index Expanded), social sciences (Social Science Citation Index), and arts and human sciences (Arts and Humanities Citation Index). All these databases can be searched in the Web of Science, available for the academic community in Brazil at the Portal of Capes (the Coordination for the Improvement of Higher Education Personnel of the Ministry of Education).

Some health journals are classified either in Science Citation Index or in Social Science Citation Index or both, depending of the content of the articles and the specialty. It is the case, for instance of psychiatry and public health. Journals of surgery and gastroenterology are indexed only in Science Citation Index or Science Citation Index Expanded.

The best known bibliometric indicators are: impact factor, immediacy index and half life. They are published annually, in CD-ROM and online, in Journal Citation Reports (JCR), another Thomson/ISI publication. JCR is published in 3 sections: Science Edition, Social Science Edition, and Arts \& Humanities Edition. The last available version of JCR, corresponding to year 2004, includes 5,968 journals in Science Edition and 1,712 in Social Science Edition, considering that there is some overlap for journals appearing in both. JCR does not include all titles indexed in the citation indexes, mainly those from Science Citation Index Expanded.

The Impact Factor is a measure of the importance or influence of a journal, taken from the citations that articles of each journal receive throughout a period of time. It was created by Eugene Garfield ${ }^{6}$, the founder of the Institute for Scientific Information, with the objective to support selection and acquisition of journals in libraries, identifying the journals most cited by researchers. Its use evolved and is currently used in the academic evaluation processes and as quality factor of the scientific output, as if offers an estimate of the prestige of the journals in which researchers publish their articles.

The Impact Factor is a ratio of the number of citations received in a given year by all articles published in the two previous years (in numerator) and the number of articles published in the same years (in denominator) ${ }^{7}$. Ej: The journal Endoscopy published 138 articles in 2002 and 152 in 2003, totaling 290 articles in both years. In the same period, it received 596 citations to articles published in 2002 and 774 for articles published in 2003, totaling 1,170 received citations. The calculation is made dividing 1,170 per 596 , that equals 4,034. The result is the Impact Factor of the journal and indicates that each article of this journal was cited, on average, 4 times.

There are several limitations and criticisms concerning the calculation and use of this indicator. ${ }^{8,9,10,11}$ Among them:

i) the calculation considers the universe of cited articles, what does not mean that they have been the only ones that were read or that were important for advancement of knowledge. According to studies conducted by ISI, $15 \%$ of whatever is published will be never be cited and $25 \%$ will be cited not more than 10 times;

ii) the type of article can influence the index, since review articles and those describing methods tend to be more cited;

iii) many journals limit the number of citations and, therefore, it is not possible to cite all what have been read;

iv) authors from developed countries tend to cite articles published in their countries and in their language, but in developing countries, authors mostly cite journals published in developed countries, preferentially those indexed in ISI databases;

v) there is no consensus that a journal with high impact factor is more useful or will have more social impact;

vi) this indicator should be used to measure the quality of journals and not of researchers. 
Journals with highest impact factors in the surgery field in 2004 are:

\begin{tabular}{lc}
\hline Title & Impact factor \\
\hline Annals of Surgery & 5,907 \\
\hline American Journal of Transplantation & 5,306 \\
\hline American Journal of Surgical Pathology & 4,690 \\
\hline Annals of Surgical Oncology & 4,035 \\
\hline Endoscopy & 4,034 \\
\hline Liver Transplantation & 3,984 \\
\hline Obesity Surgery & 3,726 \\
\hline British Journal of Surgery & 3,580 \\
\hline Transplantation & 3,568 \\
\hline Journal of Thoracic and & 3,263 \\
\hline Cardiovascular Surgery
\end{tabular}

Source: Journal Citation Reports on CD-ROM, 2004

The Immediacy Index is calculated dividing the total of citations in a given year to articles published in the same year by the total of published articles. Ej: The journal Endoscopy published 138 articles in 2004 and received 76 citations for these articles. The Immediacy Index is equal to $76 / 138$, i.e., 0,551 , meaning that $55 \%$ of the articles of this journal were cited in the same year in which they were published.

The half life index calculates the number of years taken to receiving $50 \%$ of the citations of a journal. The ratio is calculated for the citations received in a given year to articles of the same year and of previous years. In accordance with JCR of 2004, the half life of Endoscopy is 5.4, which means that $50 \%$ of the citations received in 2004 were made for articles published $4 \frac{1}{2}$ years back.

SciELO module of statistics also gives bibliometric and usage indicators, complementing the international impact indexes. Besides those, in SciELO Brazil collection there are indicators of collaboration between countries (coauthorship) and accesses to journals in the collection. The Impact Factor in SciELO is calculated for 2 and 3-year periods.

SciELO indicators make it possible to observe the patterns of the Latin American journals in the national or regional scientific communication flow. ${ }^{12,13,14}$

Figure 1 shows the evolution of the Impact Factor (calculated in a 2-year period) in SciELO Brazil, from 2001 to 2005, for two Brazilian journals of the areas of gastroenterology and surgery. Acta Cirúrgica has showed constant increase of the number of citations received from other journals in this collection.

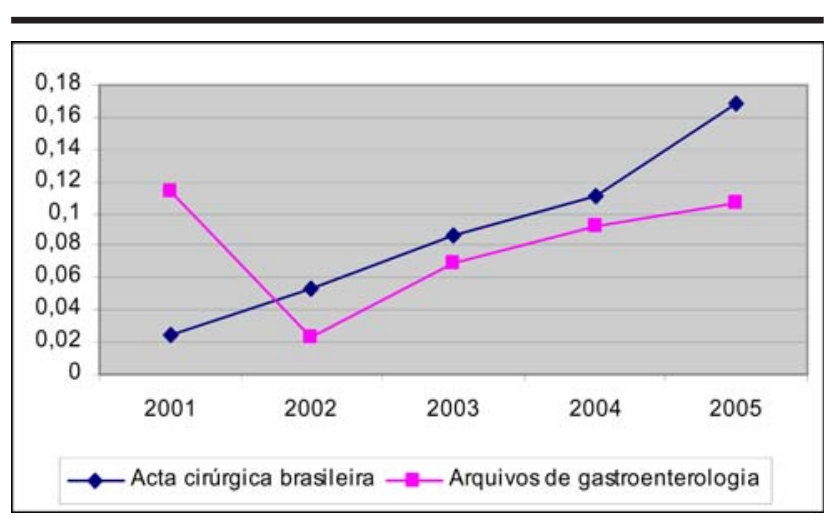

Source: SciELO Brazil

FIGURE 1 - Impact factor of Brazilian journals of surgery and gastroenterology in SciELO Brazil, 2001-2005

\section{Conclusion}

Although in the international databases the percentage of journals of gastroenterology and surgery is low, Latin American journals are well represented in regional databases as the LILACS and SciELO, which give them more visibility. The exposure caused by the SciELO is visible by the increase of citations of Acta Cirúrgica Brasileira and Arquivos de Gastroenterologia in the universe of the national journals. The availability of the full texts of journals in SciELO collections could contribute in the future to increase access and citation of articles published in these journals also by the international scientific community.

Authors, while selecting journals to publish their articles, should take into account indexing in databases, not only for scientific quality certification, but also because databases improve visibility and access, with links to full texts. However, the decision to publish in a national or in a foreign journal, or in a journal of a given specialty, should not be taken considering only the bibliometric indicators of journals, but mainly the research objectives. Researches devoted to national problems, which could have high impact in the countries, should not be published in foreign journals, where perhaps the articles will not be read or cited.

\section{References:}

1. National Library of Medicine. Fact sheet: MEDLINE. Jun 2005. Disponível na Internet: <http://0-www.nlm.nih.gov.csulib.ctstateu.edu/pubs/ factsheets/medline.html>

2. National Library of Medicine. Fact sheet: What's the difference between MEDLINE and PubMed? Dez 2004. Disponível na Internet: <http://0-www.nlm.nih.gov.csulib.ctstateu.edu/pubs/ factsheets/dif med pub.html>

3. National Library of Medicine. Bibliographic Services Division. Number of titles currently indexed for Index Medicus and MEDLINE on PubMed. Dec 2005. Disponível na Internet: $<$ http://0-www.nlm.nih.gov.csulib.ctstateu.edu/bsd/ num titles.html>

4. Población DA, Goldenberg S, Montero EFS, Moreira MB, 
Pellizzon RF. Revistas brasileiras publicadoras de artigos científicos em cirurgia. I - Características estruturais e administrativas das revistas. Acta Cir Bras. 2002;17(6):359-69. Disponível na Internet: < http://ww w.scielo.br/scielo.php?

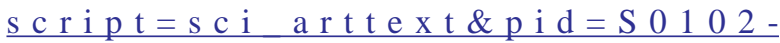
$86502002000600002 \& \operatorname{lng}=\mathrm{pt}>$.

5. Población DA, Goldenberg S, Montero EFS, Gomes PO, Campanatti-Ostiz H, Moreira MB, Santos AC, Pellizzon RF. Revistas brasileiras publicadoras de artigos científicos em cirurgia. II - Terminologia e atribuições adotadas pelos editores. Proposta de organograma do periódico e fluxograma do artigo. Acta Cir. Bras. 2003;18(6):497-501. Disponível na Internet: $<$ http://ww w.scielo.br/scielo.php?

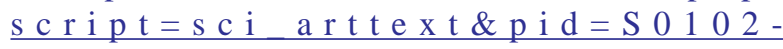
$86502003000600003 \& \operatorname{lng}=p t>$.

6. Garfield E. The agony and the ecstasy - The history and meaning of the impact factor. In: International Congress on Peer Review and Biomedical Publication, Chicago, September 16, 2005. Disponível na Internet: < http://garfield.library.upenn.edu/papers/ jifchicago2005.pdf>

7. The ISI impact factor. Curr Contents. Jun. 201994. Disponível na Internet: $<$ http://scientific.thomson.com/ free/essays/journalcitationreports/impactfactor/>

8. Coelho PMZ, Antunes CMF, Costa HMA, Kroon EG, Sousa Lima MC, Linardi PM. The use and misuse of the "impact factor" as a parameter for evaluation of scientific publications quality: a proposal to rationalize its application. Braz. j. med. biol. res. 2003;36(12):1605-12. Disponível na Internet: <http://www.scielo.br/

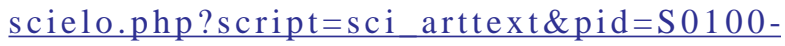
$\underline{\text { 879X2003001200001\&lng=pt> }}$
9. Benitez-Bribiesca, L. The ups and downs of the impact factor: the case of Archives of Medical Research. Arch. med. res. 2002;33:91-94.

10.Coura JR, Willcox, LCB. Impact factor evolution on Memórias do Instituto Oswaldo Cruz. Mem. Inst. Oswaldo Cruz. 2005;100(5):457-8. Disponível na Internet: $<$ ht t : / / w w w. scielo.br/scielo.php? script $=$ sci arttext \& pid = S 0074 $02762005000500001 \& \operatorname{lng}=\mathrm{pt}>$.

11.Porta M, Copete JL, Fernandez E, Alguacil J, Murillo J. Mixing journal, article, and author citations, and other pitfalls in the bibliographic impact factor. Cad. Saúde Pública. 2003; 19(6):1847-62. Disponível na Internet: < ht t p:// w w w.scielo.br/scielo.php? script $=$ sci arttext \& pid =S 0102 311X2003000600030\&lng=pt $>$.

12.Coura JR, Willcox LCB. Fator de impacto, produção científica e qualidade das revistas médicas brasileiras. Mem. Inst. Oswaldo Cruz. 2003;98(3):293-8. Disponível na Internet: <http://www.scielo.br/scielo.php ? script =s ci arttext\&pid=S0074$\underline{02762003000300001 \& \operatorname{lng}=p t>}$

13.Medeiros AC. O fator de impacto da Acta Cirúrgica Brasileira. Acta Cir. Bras. 2003;18(2):74-5. Disponível na Internet: $\quad<$ http://www.scielo.br/scielo.php? s c r i p t $=$ s c i a r t t ext \& pi d = S 0102 86502003000200001\&lng=pt>

14.Alonso WJ.; Fernández-Juricic E. Regional network raises profile of local journals. Nature 2002;415. Disponível na Internet: <http://www.nature.com/login/ scidev login.taf?ref=/nature/journal/v415/n6871/full/ 415471c_fs.html>.
Correspondence:

Regina C. Figueiredo Castro

R. Botucatu, 862

04023-901 São Paulo - SP Brasil

castrore@bireme.ops-oms.org
Conflict of interest: none Financial source: none

Received: February 23, 2006

Review: March 21, 2006

Accepted: April 15, 2006

\section{How to cite this article:}

Castro RCF. Journals in surgery and gastroenterology: indexing in databases and bibliometric indicators. Acta Cir Bras. [serial on the Internet] 2006 May-June;21(3). Disponível em URL: http://www.scielo.br/acb 